\title{
No Commonality in Liquidity on Small Emerging Markets? Evidence from the Central and Eastern European Stock Exchanges ${ }^{1}$
}

\author{
Joanna Olbryś \\ Ph.D., Associate Professor, Bialystok University of Technology \\ Faculty of Computer Science, Department of Theoretical Computer Scnience \\ Bialystok, Poland, e-mail: j.olbrys@pb.edu.pl
}

\section{Abstract}

The goal of this comparative research is to investigate intra-market commonality in liquidity on six small emerging Central and Eastern European (CEE) stock exchanges - in the Czech Republic, Hungary, Slovakia, Lithuania, Estonia, and Latvia. The CEE post-communist countries can be analyzed together as they are geographically close, and the stock markets are relatively similar. Three measures based on daily data are utilized as liquidity/ illiquidity proxies: (1) a modified version of the Amihud (2002) measure, (2) the percentage relative spread, and (3) the Corwin-Schultz (2012) high-low two-day spread estimator. The OLS regression with the HAC covariance matrix estimation and the GARCH-type models are employed to explore the patterns of market-wide commonality in liquidity on the CEE stock exchanges. The main value-added comes from the methodology and the novel empirical findings. To the best of the author's knowledge, this is the first study that investigates commonality in liquidity in the aforementioned group of countries using three liquidity proxies and the time rolling-window approach to provide robustness tests. The regressions reveal no pronounced evidence of co-movements in liquidity within the CEE markets, taken separately. What is important, the empirical results are homogeneous for all investigated markets. Therefore, no reason has been found to reject the research hypothesis that there is no commonality in liquidity on each individual market. This paper aspires to fill the gap in the knowledge of liquidity patterns on the CEE emerging markets.

Keywords: Central and Eastern Europe, commonality in liquidity, GARCH, OLS-HAC, time rolling-window, daily data

JEL: C32, C58, G12, G15, O52

1 This research was supported by grant No. 2016/21/B/HS4/02004 from the National Science Centre, Poland. 


\section{Introduction}

According to the literature, the existence of commonality in liquidity indicates that individual company liquidity is sensitive to changes in aggregate stock market liquidity. It is well documented that assessing co-movements in liquidity is important for a number of reasons. There are some crucial topics that are especially frequently investigated in this context, including the consideration of commonality in liquidity in non-classical asset pricing models since it could represent a source of non-diversifiable risk, the relationship between shareholders structure and individual firm liquidity, the influence of commonality in liquidity on investment strategies, and the importance of commonality in liquidity to regulators and central bankers (Olbryś 2019a, p. 252). Narayan et al. (2015) emphasize that empirical evidence of common liquidity movements would assist regulators in improving stock market design.

Bekaert et al. (2007) pointed out that liquidity is more critical for emerging than developed markets. The six small Central and Eastern European (CEE) stock exchanges are emerging markets, but four of them (Slovakia, Lithuania, Estonia, and Latvia) are, in fact, frontier markets (Kiviaho et al. 2014). Therefore, one might expect them to be very sensitive to changes in liquidity. Moreover, Brockman et al. (2009) examined the impact of domestic macroeconomic announcements on commonality in liquidity for individual stock exchanges, and their results revealed that the announcement effects are stronger for emerging markets as a group than for developed markets. The small post-communist CEE stock exchanges can be analyzed as a group of markets because they are geographically close and relatively similar. Taking the above into consideration, one might expect that commonality in liquidity exists on these markets. Unfortunately, a large number of companies listed on the CEE exchanges reveal a substantial non-trading problem (Olbryś 2018). The non-trading effect means there is a lack of transactions over a particular period when an exchange is open for trading, with illiquidity as its consequence. Therefore, in the current paper, the research hypothesis that there is no commonality in liquidity on each individual CEE stock market is tested.

The goal of this comparative research is to thoroughly investigate intra-market co-movements in liquidity on six small CEE stock markets - in the Czech Republic, Hungary, Slovakia, Lithuania, Estonia, and Latvia. The Polish stock exchange is not included in this study because it is large compared to the other CEE stock exchanges in the region. However, intra-market commonality in liquidity on the Warsaw Stock Exchange has recently been quite deeply explored in the papers (e.g., Olbryś 2019a; Będowska-Sójka 2019). The empirical results revealed rather weak evidence of co-movements in liquidity on the WSE, regardless of the choice of liquidity proxy.

It is worth noting that Olbryś (2018) conducted a preliminary study of commonality in liquidity on the small CEE exchanges in the context of the non-trading problem. A modified version of the Amihud (2002) measure was used as a daily liquidity proxy in the period from January 2, 2012, to December 30, 2016. The classical market model 
of liquidity proposed by Chordia et al. (2000) was employed. The empirical results revealed no evidence of commonality in liquidity on any of the investigated CEE stock markets. To confirm this phenomenon, in the current research, the daily percentage relative spread and Corwin and Schultz's (2012) high-low spread estimator are utilized as additional liquidity proxies. The common feature of the measures used in the study is that they are all based on daily data and are calculated in daily frequency. Moreover, the time rolling-window approach is used to test the stability of the empirical findings in different sub-periods. Following Olbryś (2018), the classical market model of liquidity is utilized in this study. The OLS regression with the HAC covariance matrix estimation (Newey, West 1987) and the GARCH-type models (if necessary, as the OLS-HAC may not fully accommodate the ARCH effect) are employed to infer the patterns of commonality in liquidity.

The main contribution of this research lies in its thorough assessment of commonality in liquidity on six small CEE stock exchanges. The value-added derives from the methodology and the novel empirical findings. To the best of the author's knowledge, this is the first study that investigates commonality in liquidity in the aforementioned group of countries using three liquidity proxies and the time rolling-window approach to provide robustness tests. The regressions reveal no pronounced evidence of commonality in liquidity on the CEE stock markets, taken separately. Importantly, the empirical findings are homogeneous for all investigated markets. It means that individual firm liquidity is not significantly influenced by co-movements in the liquidity of all other firms traded on the same exchange. The findings fill the gap in the knowledge of commonality in liquidity on emerging and frontier stock markets. According to the literature, the results for the CEE stock exchanges reported in this paper substantially differ from findings that have been obtained for developed markets around the world.

The remainder of the study is organized as follows. Section 2 provides a brief literature review of commonality in liquidity on emerging markets. Section 3 specifies the methodological background concerning the measurement of commonality in liquidity. Section 4 describes the data and discusses the empirical results for the six stock exchanges. The paper is summarized in the presentation of conclusions, implications for practice, as well as limitations and suggestions for further research.

\section{Commonality in liquidity on emerging markets}

The first empirical study of commonality in liquidity was conducted by Chordia et al. (2000). Beginning with this seminal paper, identifying commonality in liquidity emerged as a fast-growing strand of the literature on liquidity, especially for the U.S. stock market (e.g., Chordia et al. 2000; Kamara et al. 2008; Kang, Zhang 2013; Korajczyk, Sadka 2008). Commonality in liquidity has also been explored for other individual emerging and developed equity markets in the world. In general, the em- 
pirical results from various markets are ambiguous. The majority of researchers suggest that market structure and trading mechanisms play important roles in different effects of commonality in liquidity for the observed markets. Moreover, the non-trading problem may substantially affect the findings of liquidity co-movements on small emerging stock exchanges. This is because infrequently traded stocks cannot provide reliable information.

Kearney (2012) pointed out that although the term "emerging market" is in common usage, there is no agreement on either the theoretical or operational definition of what it constitutes, and the classification of countries as emerging markets is consequently somewhat arbitrary. As this research aspires to draw attention toward emerging economies, the analysis of previous literature focuses on studies that relate mostly to emerging stock exchanges. However, the majority of papers concern Asian emerging markets, which, in general, are not comparable to European small stock exchanges. For example, Pukthuanthong-Le and Visaltanachoti (2009) assessed the Stock Exchange in Thailand, and they confirmed market-wide commonality in liquidity on this market. Narayan et al. (2015) found strong support for commonality in liquidity on the Chinese stock exchanges in Shanghai and Shenzhen. Syamala et al. (2017) analyzed the Indian stock market, and presented evidence for both supply-side and demand-side factors that contribute to liquidity commonality. Wang (2013) examined the impact of a set of common factors on liquidity variations on eight emerging equity markets in Asia, namely China, India, Indonesia, Korea, Malaysia, the Philippines, Taiwan, and Thailand. Meanwhile, Sensoy (2016) investigated the influence of specific macro-announcements on liquidity commonality in Turkey.

A limited number of studies investigate commonality in liquidity for a group of equity markets, with Central and Eastern European economies receiving particularly little attention. For example, Brockman et al. (2009) utilized the methodology of Chordia et al. (2000) on 47 stock markets from different contingent-based regions, but their database included only two of the CEE countries, namely Poland and Hungary. Karolyi et al. (2012) analyzed cross-country commonality in liquidity using daily data for stocks from 40 developed and emerging markets, but their database contained only the Polish stock exchange. Bai and Qin (2015) investigated commonality in liquidity in 18 emerging countries, but, as with Karolyi et al., only Poland was included in their research. Importantly, the authors pointed out that liquidity co-movements across emerging stock exchanges have a pronounced geographic component. This evidence might be crucial in the case of CEE countries that are geographically close. Olbryś (2019b) assessed market-wide commonality in liquidity on the CEE-3 stock exchanges in Poland, the Czech Republic, and Hungary. The empirical findings confirmed weak evidence of co-movements in liquidity on the analyzed markets, considered separately.

None of the aforementioned studies concerns the whole group of the CEE countries. Table 1 includes brief information on the six small stock markets that are investigated in this research, namely the Czech Republic, Hungary, Slovakia, Lithuania, Estonia, and Latvia. 
Table 1. The six small Central and Eastern European stock markets highlights

\begin{tabular}{|l|c|c|c|c|}
\hline \multicolumn{1}{|c|}{ Country } & Stock exchange & Index & $\begin{array}{c}\text { Stock market } \\
\text { established }\end{array}$ & $\begin{array}{c}\text { Market Cap., EUR billion, } \\
\text { Dec 2016 }\end{array}$ \\
\hline $\begin{array}{l}\text { Czech } \\
\text { Republic }\end{array}$ & $\begin{array}{c}\text { Prague Stock } \\
\text { Exchange (PSE) }\end{array}$ & PX & 1993 & 22.19 \\
\hline Hungary & $\begin{array}{c}\text { Budapest Stock } \\
\text { Exchange (BSE) }\end{array}$ & BUX & 1991 & 21.27 \\
\hline Slovakia & $\begin{array}{c}\text { Bratislava Stock } \\
\text { Exchange (BSSE) }\end{array}$ & SAX & 1993 & 5.28 \\
\hline Lithuania & NASDAQ Vilnius & OMXV & 1993 & 3.50 \\
\hline Estonia & NASDAQ Tallinn & OMXT & 1995 & 2.29 \\
\hline Latvia & NASDAQ Riga & OMXR & 1995 & 0.80 \\
\hline
\end{tabular}

Source: National stock exchange websites.

\section{Methodology}

In this section, the methodological background concerning the measurement of commonality in liquidity is presented. Selected liquidity/illiquidity proxies derived from daily data and econometric methods applied in the study are described in detail.

\section{Liquidity proxies derived from daily data}

An investigation of liquidity is complicated by various obstacles. A lack of access to intraday data on most emerging stock markets might be considered one such inconvenience, and it is a problem that is widely known and amply reported in the literature (e.g., Bekaert et al. 2007; Olbryś 2014). High-frequency data are not freely available for the analyzed CEE stock exchanges. Therefore, in this study, three liquidity proxies approximated from daily data are utilized to capture various sources of market liquidity, which is, in fact, a latent variable. Table 2 presents the formulas of these proxies.

Table 2. Definition of daily liquidity/illiquidity proxies utilized in the study

\begin{tabular}{|c|c|c|}
\hline & Liquidity proxy & Definition \\
\hline 1 & $\begin{array}{l}\text { The modified version of the Amihud (2002) } \\
\text { measure } M A m i h_{t}\end{array}$ & MAmih $_{t}=\left\{\begin{array}{c}\log \left(1+\frac{\left|r_{t}\right|}{V_{t}}\right), \text { when } V_{t} \neq 0 \\
0, \text { when } V_{t}=0\end{array}\right.$ \\
\hline 2 & The percentage relative spread $\% R S_{t}$ & $\% R S_{t}=\frac{200 \cdot\left(P_{t}^{H}-P_{t}^{L}\right)}{P_{t}^{H}+P_{t}^{L}}$ \\
\hline
\end{tabular}


Tabel 2. (continued)

\begin{tabular}{|l|l|c|}
\cline { 2 - 3 } \multicolumn{1}{c|}{ Liquidity proxy } & Definition \\
\hline 3 & $\begin{array}{l}\text { The Corwin-Schultz (2012) high-low two-day } \\
\text { spread estimator } S_{t}\end{array}$ & $S_{t}=\frac{2\left(e^{\alpha}-1\right)}{e^{\alpha}+1}$ \\
\hline
\end{tabular}

Where:

$r_{t}$ is the simple rate of return of stock on day $t$,

$V_{t}$ is the trading volume of stock on day $t$,

$P_{t}^{H}, P_{t}^{L}$ are the high and low prices of stock on day $t$, respectively,

$\alpha=\frac{\sqrt{2 \beta}-\sqrt{B}}{3-2 \sqrt{2}}-\sqrt{\frac{\gamma}{3-2 \sqrt{2}}}$ is the main parameter in the formula for the $S_{t}$ estimator,

$\beta=\left[\ln \left(\frac{P_{t}^{H}}{P_{t}^{L}}\right)\right]^{2}+\left[\ln \left(\frac{P_{t+1}^{H}}{P_{t+1}^{L}}\right)\right]^{2}, \gamma=\left[\ln \left(\frac{\max \left(P_{t}^{H}, P_{t+1}^{H}\right)}{\max \left(P_{t}^{L}, P_{t+1}^{L}\right)}\right)\right]^{2}$.

Source: author's own elaboration based on Karolyi et al. 2012; Olbrys, Mursztyn 2018; Olbryś 2019a; and Corwin, Schultz 2012.

Table 2 requires some comments. The value of the daily proxy $M A m i h_{t}$ is defined to be equal to zero when the total daily volume is equal to zero. In the literature, the Amihud measure is usually calculated for a stock for each month (e.g., Fong et al. 2017; Olbryś 2014). However, in this study, daily time series of the modified Amihud proxy are estimated. The percentage relative spread $\% R S_{t}$ is a measure of illiquidity because a high value of this indicator denotes low liquidity while a small value of the $\% R S_{t}$ indicates high liquidity. The $S_{t}$ estimator is quite easy to compute as it requires only the high and low prices from two consecutive days, $t$ and $t+1$. It is calculated for a stock on each trading day. However, Corwin and Schultz (2012) emphasize that infrequent trading is a crucial problem if all trades occur at the same price, and then $P_{t}^{H}=P_{t}^{L}$ . In fact, the $S_{t}$ measures illiquidity, so usually the higher are the values of this indicator, the lower liquidity is observed on a given day.

\section{Assessing commonality in liquidity}

To investigate commonality in liquidity, the classical market model of liquidity proposed by Chordia et al. (2000) is the most frequently employed model in the literature. In this research, a modified version of this model, including the Dimson (1979) correction for daily data, is applied:

$$
D L_{i, t}=\alpha_{i}+\beta_{i,-1} \cdot D L_{M, t-1}+\beta_{i, 0} \cdot D L_{M, t}+\beta_{i,+1} \cdot D L_{M, t+1}+\varepsilon_{i, t},
$$


where $D L_{i, t}$ for stock $i$ is the change in liquidity variable $L$ from trading day $t-1$ to $t$, i.e., $D L_{t}=\frac{L_{t}-L_{t-1}}{L_{t-1}}$. The Dimson correction allows us to mitigate the non-synchronous trading problem. In this procedure, the $D L_{M, t-1}, D L_{M, t}$, and $D L_{M, t+1}$ variables are included in the model equation. These variables are the lagged, concurrent, and leading changes is a cross-sectional average of the liquidity variable $L$, respectively. It is crucial that in computing the 'market' liquidity proxy $L_{M}$, stock $i$ is excluded and the measure $L_{M}$. is estimated as the equally-weighted average liquidity for the remaining stocks, for each individual stock market, so the explanatory variables in the model (1) are slightly different for each stock regression (Olbryś 2019a, p. 262). Positive and statistically significant slope coefficients $\beta_{i, 0}, \beta_{i,-1}$, and $\beta_{i,+1}$ are especially desired since they indicate commonality in liquidity. Basically, they confirm liquidity co-movements in the same direction (e.g., Brockman et al. 2009; Olbryś 2018; 2019a; 2019b).

Model (1) is initially estimated for each stock by the OLS regression with the robust HAC estimates (Newey, West 1987), but the OLS-HAC may not fully correct for the influence problems introduced by the ARCH effect. In such cases, estimating model (1) as a GARCH-type model is more appropriate. Engle's (1982) test is employed to infer the ARCH effect. The GARCH(p, q) model is defined by Eq. (2):

$$
\begin{gathered}
D L_{i, t}=\alpha_{i}+\beta_{i,-1} \cdot D L_{M, t-1}+\beta_{i, 0} \cdot D L_{M, t}+\beta_{i,+1} \cdot D L_{M, t+1}+\varepsilon_{i, t}, \\
\varepsilon_{i, t}=z_{i, t} \sqrt{\mathrm{h}_{\mathrm{i}, \mathrm{t}}}, z_{i, t} \sim N(0,1), \\
\mathrm{h}_{\mathrm{i}, \mathrm{t}}=a_{i, 0}+\sum_{k=1}^{q} a_{i, k} \varepsilon_{i, t-k}^{2}+\sum_{l=1}^{p} b_{i, l} \mathrm{~h}_{\mathrm{i}, \mathrm{t}-\mathrm{l}},
\end{gathered}
$$

where $a_{i, 0}>0, a_{i, k} \geq 0, k=1, \ldots, q, q>0, b_{i, l} \geq 0, l=, \ldots, p, p \geq 0$. The $\varepsilon_{i, t}$ is the innovation in a linear regression with $V(\varepsilon)=\sigma^{2}$, while $h_{i, t}$ is the variance function. The rest of the notation is the same as in Eq. (1) (see for example Olbryś 2018; 2019a; 2019b).

\section{Data description and empirical results on the CEE stock exchanges}

In the present study, daily data for stock exchanges from the Czech Republic, Hungary, Slovakia, Lithuania, Estonia, and Latvia, are utilized. Data comes from Bloomberg under a license agreement between Bloomberg and Bialystok University of Technology (grant No. 2016/21/B/HS4) ${ }^{2}$. The database contains the opening, high, low, and

2 The database was prepared specifically for the grant and it was purchased from Bloomberg in January 2017. Therefore, to avoid internal inconsistency of the research, all empirical analyses concerning various aspects of liquidity for the six stock markets were conducted for the same period from January 2012 to December 2016 (e.g., Olbryś 2018; 2020). 
closing prices, as well as the volume for each equity over each trading day, from January 2, 2012, to December 30, 2016. The database holds 1252 (for the PSE), 1240 (for the BSE), 1244 (for the BSSE), 1245 (for the NASDAQ Vilnius), 1251 (for the NASDAQ Tallinn), and 1242 (for the NASDAQ Riga) trading days, respectively. The Warsaw Stock Exchange (WSE) is not included in the study because it is large compared to the other CEE stock markets. For comparison, at the end of 2016, the total number of listed companies was 881 (WSE), 23 (PSE), 41 (BSE), 71 (BSSE), 34 (NASDAQ Vilnius), 17 (NASDAQ Tallinn), and 32 (NASDAQ Riga) (Olbryś 2018, p. 72).

It is widely known that a lot of equities listed on emerging stock markets display a substantial non-trading problem. To avoid this problem, the companies that exhibited an extraordinarily high number of non-traded days within the whole sample period (precisely, above 373 zeros in daily volume, which constituted about $30 \%$ of all trading days), were excluded from the data set. Finally, the database contained 10 (Prague), 18 (Budapest), 3 (Bratislava), 15 (Vilnius), 12 (Tallinn), and 7 (Riga) companies (65 firms in total) (Olbryś 2018, p. 73).

\section{Testing for stock exchange-level commonality in liquidity}

In the first step, using the ADF-GLS test (Elliott et al. 1996) or ADF test (Dickey, Fuller 1981), I tested whether the daily time series are stationary. It was proved that the unitroot hypothesis can be rejected at the $5 \%$ significance level for all time series utilized in the study. In order to reduce the effects of possibly spurious outliers, the data was 'winsorized' by the $1^{\text {st }}$ and $99^{\text {th }}$ percentiles for each time series (e.g., Korajczyk, Sadka 2008; Kamara et al. 2008).

In the second step, the OLS-HAC regression was employed to estimate the parameters of model (1). In total, 195 models for the six stock markets and three liquidity proxies $\left(M A m i h_{t}, \% R S_{t}\right.$, and $S_{t}$ ) were estimated, comprising 30 (Prague), 54 (Budapest), 9 (Bratislava), 45 (Vilnius), 36 (Tallinn), and 21 (Riga). For each stock, the daily proportional changes in individual stock liquidity variables were regressed in time-series on the changes of an equally weighted cross-sectional average of the liquidity variable for all stocks in the sample, excluding the dependent variable stock (Olbryś 2019a, p. 264). The empirical results showed that the OLS-HAC regressions proved to be appropriate for 29 models (Prague), 42 models (Budapest), 8 models (Bratislava), 35 models (Vilnius), 30 models (Tallinn), and 20 models (Riga) because the ARCH effect did not appear. Only for 31 models was the ARCH effect in the residuals detected. Therefore, for those companies, the GARCH(p, q), p, $q=1,2$ models (2) were estimated. The number of lags p, q, was selected on the basis of the AIC and SC information criteria.

The cross-sectional estimation results of models (1) and (2) are presented in Table 3. This table contains the number of positive significant, positive insignificant, negative significant, and negative insignificant coefficients (at the 10\% significance level), for each stock exchange and each liquidity proxy, separately. 
No Commonality in Liquidity on Small Emerging Markets...

Table 3. Testing for commonality in liquidity on the CEE stock markets

\begin{tabular}{|c|c|c|c|c|c|c|}
\hline \multicolumn{7}{|c|}{ Prague Stock Exchange (10 companies) } \\
\hline & \multicolumn{2}{|c|}{ MAmih $_{t}$} & \multicolumn{2}{|c|}{$\% R S_{t}$} & \multicolumn{2}{|c|}{$S_{t}$} \\
\hline & $\begin{array}{l}\text { OLS-HAC } \\
9 \text { models }\end{array}$ & $\begin{array}{l}\text { GARCH } \\
1 \text { model }\end{array}$ & $\begin{array}{l}\text { OLS-HAC } \\
10 \text { models }\end{array}$ & $\begin{array}{l}\text { GARCH } \\
0 \text { model }\end{array}$ & $\begin{array}{l}\text { OLS-HAC } \\
10 \text { models }\end{array}$ & $\begin{array}{l}\text { GARCH } \\
0 \text { model }\end{array}$ \\
\hline \multicolumn{7}{|c|}{ Concurrent $\beta_{i, 0}$} \\
\hline++ & 2 & 0 & 6 & - & 1 & - \\
\hline+ & 3 & 0 & 4 & - & 3 & - \\
\hline-- & 2 & 0 & 0 & - & 2 & - \\
\hline- & 2 & 1 & 0 & - & 4 & - \\
\hline \multicolumn{7}{|c|}{$\operatorname{Lag} \beta_{i,-1}$} \\
\hline++ & 0 & 0 & 4 & - & 0 & - \\
\hline+ & 4 & 0 & 2 & - & 8 & - \\
\hline-- & 2 & 0 & 0 & - & 0 & - \\
\hline- & 3 & 1 & 4 & - & 2 & - \\
\hline \multicolumn{7}{|c|}{ Lead $\beta_{i,+1}$} \\
\hline++ & 0 & 1 & 1 & - & 0 & - \\
\hline+ & 2 & 0 & 5 & - & 4 & - \\
\hline-- & 2 & 0 & 0 & - & 2 & - \\
\hline- & 5 & 0 & 4 & - & 4 & - \\
\hline \multicolumn{7}{|c|}{ Budapest Stock Exchange (18 companies) } \\
\hline & \multicolumn{2}{|c|}{$\mathrm{MAmih}_{\mathrm{t}}$} & \multicolumn{2}{|c|}{$\% R S_{t}$} & \multicolumn{2}{|c|}{$S_{t}$} \\
\hline & $\begin{array}{l}\text { OLS-HAC } \\
14 \text { models }\end{array}$ & $\begin{array}{c}\text { GARCH } \\
4 \text { models }\end{array}$ & $\begin{array}{l}\text { OLS-HAC } \\
14 \text { models }\end{array}$ & $\begin{array}{c}\text { GARCH } \\
4 \text { models }\end{array}$ & $\begin{array}{l}\text { OLS-HAC } \\
14 \text { models }\end{array}$ & $\begin{array}{c}\text { GARCH } \\
4 \text { models }\end{array}$ \\
\hline \multicolumn{7}{|c|}{ Concurrent $\beta_{i, 0}$} \\
\hline++ & 0 & 0 & 6 & 3 & 2 & 0 \\
\hline+ & 5 & 0 & 5 & 1 & 4 & 2 \\
\hline-- & 3 & 1 & 1 & 0 & 3 & 1 \\
\hline- & 6 & 3 & 2 & 0 & 5 & 1 \\
\hline \multicolumn{7}{|c|}{$\operatorname{Lag} \beta_{\mathrm{i},-1}$} \\
\hline++ & 1 & 0 & 2 & 1 & 1 & 0 \\
\hline+ & 1 & 3 & 7 & 2 & 5 & 2 \\
\hline-- & 6 & 0 & 2 & 0 & 1 & 0 \\
\hline- & 6 & 1 & 3 & 1 & 7 & 2 \\
\hline \multicolumn{7}{|c|}{ Lead $\beta_{i,+1}$} \\
\hline++ & 1 & 0 & 4 & 1 & 0 & 0 \\
\hline+ & 6 & 1 & 7 & 1 & 3 & 1 \\
\hline-- & 4 & 1 & 1 & 0 & 0 & 2 \\
\hline- & 3 & 2 & 2 & 2 & 11 & 1 \\
\hline
\end{tabular}


Joanna Olbryś

Tabel 3. (continued)

\begin{tabular}{|c|c|c|c|c|c|c|}
\hline \multicolumn{7}{|c|}{ Bratislava Stock Exchange (3 companies) } \\
\hline & \multicolumn{2}{|c|}{$\mathrm{MAmih}_{\mathrm{t}}$} & \multicolumn{2}{|c|}{$\% R S_{t}$} & \multicolumn{2}{|c|}{$S_{t}$} \\
\hline & $\begin{array}{l}\text { OLS-HAC } \\
3 \text { models }\end{array}$ & $\begin{array}{l}\text { GARCH } \\
0 \text { model }\end{array}$ & $\begin{array}{l}\text { OLS-HAC } \\
2 \text { models }\end{array}$ & $\begin{array}{l}\text { GARCH } \\
1 \text { model }\end{array}$ & $\begin{array}{l}\text { OLS-HAC } \\
3 \text { models }\end{array}$ & $\begin{array}{l}\text { GARCH } \\
0 \text { model }\end{array}$ \\
\hline \multicolumn{7}{|c|}{ Concurrent $\beta_{\mathrm{i}, 0}$} \\
\hline++ & 0 & - & 0 & 0 & 0 & - \\
\hline+ & 3 & - & 2 & 1 & 1 & - \\
\hline-- & 0 & - & 0 & 0 & 0 & - \\
\hline- & 0 & - & 0 & 0 & 2 & - \\
\hline \multicolumn{7}{|c|}{$\operatorname{Lag} \beta_{i,-1}$} \\
\hline++ & 0 & - & 0 & 0 & 0 & - \\
\hline+ & 1 & - & 2 & 0 & 2 & - \\
\hline-- & 1 & - & 0 & 0 & 0 & - \\
\hline- & 1 & - & 0 & 1 & 1 & - \\
\hline \multicolumn{7}{|c|}{ Lead $\beta_{i,+1}$} \\
\hline++ & 0 & - & 0 & 0 & 0 & - \\
\hline+ & 1 & - & 0 & 1 & 2 & - \\
\hline-- & 1 & - & 1 & 0 & 0 & - \\
\hline- & 1 & - & 1 & 0 & 1 & - \\
\hline \multicolumn{7}{|c|}{ NASDAQ Vilnius (15 companies) } \\
\hline & \multicolumn{2}{|c|}{$\mathrm{MAmih}_{\mathrm{t}}$} & \multicolumn{2}{|c|}{$\% R S_{t}$} & \multicolumn{2}{|c|}{$S_{t}$} \\
\hline & $\begin{array}{l}\text { OLS-HAC } \\
14 \text { models }\end{array}$ & $\begin{array}{l}\text { GARCH } \\
1 \text { model }\end{array}$ & $\begin{array}{l}\text { OLS-HAC } \\
12 \text { models }\end{array}$ & $\begin{array}{c}\text { GARCH } \\
3 \text { models }\end{array}$ & $\begin{array}{l}\text { OLS-HAC } \\
9 \text { models }\end{array}$ & $\begin{array}{l}\text { GARCH } \\
6 \text { models }\end{array}$ \\
\hline \multicolumn{7}{|c|}{ Concurrent $\beta_{i, 0}$} \\
\hline++ & 0 & 0 & 5 & 1 & 0 & 1 \\
\hline+ & 9 & 0 & 6 & 2 & 4 & 4 \\
\hline-- & 1 & 0 & 0 & 0 & 0 & 0 \\
\hline- & 4 & 1 & 1 & 0 & 5 & 1 \\
\hline \multicolumn{7}{|c|}{$\operatorname{Lag} \beta_{\mathrm{i},-1}$} \\
\hline++ & 0 & 0 & 2 & 1 & 2 & 1 \\
\hline+ & 3 & 0 & 9 & 2 & 5 & 4 \\
\hline-- & 5 & 0 & 0 & 0 & 0 & 0 \\
\hline- & 6 & 1 & 1 & 0 & 2 & 1 \\
\hline \multicolumn{7}{|c|}{ Lead $\beta_{i,+1}$} \\
\hline++ & 0 & 0 & 2 & 0 & 1 & 1 \\
\hline+ & 9 & 1 & 3 & 2 & 2 & 1 \\
\hline-- & 2 & 0 & 0 & 0 & 0 & 0 \\
\hline- & 3 & 0 & 7 & 1 & 6 & 4 \\
\hline
\end{tabular}


No Commonality in Liquidity on Small Emerging Markets...

\begin{tabular}{|c|c|c|c|c|c|c|}
\hline \multicolumn{7}{|c|}{ NASDAQ Tallinn (12 companies) } \\
\hline & \multicolumn{2}{|c|}{$\mathrm{MAmih}_{t}$} & \multicolumn{2}{|c|}{$\% R S_{t}$} & \multicolumn{2}{|c|}{$S_{t}$} \\
\hline & $\begin{array}{l}\text { OLS-HAC } \\
11 \text { models }\end{array}$ & $\begin{array}{l}\text { GARCH } \\
1 \text { model }\end{array}$ & $\begin{array}{l}\text { OLS-HAC } \\
10 \text { models }\end{array}$ & $\begin{array}{c}\text { GARCH } \\
2 \text { models }\end{array}$ & $\begin{array}{l}\text { OLS-HAC } \\
9 \text { models }\end{array}$ & $\begin{array}{c}\text { GARCH } \\
3 \text { models }\end{array}$ \\
\hline \multicolumn{7}{|c|}{ Concurrent $\beta_{i, 0}$} \\
\hline++ & 0 & 0 & 5 & 0 & 0 & 0 \\
\hline+ & 6 & 1 & 3 & 0 & 3 & \\
\hline-- & 2 & 0 & 0 & 0 & 1 & 1 \\
\hline- & 3 & 0 & 2 & 2 & 5 & 1 \\
\hline \multicolumn{7}{|c|}{$\operatorname{Lag} \beta_{i,-1}$} \\
\hline++ & 0 & 0 & 1 & 0 & 0 & 1 \\
\hline+ & 2 & 0 & 6 & 1 & 3 & 0 \\
\hline-- & 5 & 0 & 1 & 1 & 0 & 2 \\
\hline- & 4 & 1 & 2 & 0 & 6 & 0 \\
\hline \multicolumn{7}{|c|}{ Lead $\beta_{\mathrm{i},+1}$} \\
\hline++ & 0 & 0 & 1 & 0 & 1 & 0 \\
\hline+ & 1 & 0 & 3 & 0 & 3 & 2 \\
\hline-- & 3 & 0 & 1 & 2 & 0 & 1 \\
\hline- & 7 & 1 & 5 & 0 & 5 & 0 \\
\hline \multicolumn{7}{|c|}{ NASDAQ Riga (7 companies) } \\
\hline & \multicolumn{2}{|c|}{ MAmih $_{t}$} & & & \multicolumn{2}{|c|}{$S_{t}$} \\
\hline & $\begin{array}{l}\text { OLS-HAC } \\
7 \text { models }\end{array}$ & $\begin{array}{l}\text { GARCH } \\
0 \text { model }\end{array}$ & $\begin{array}{l}\text { OLS-HAC } \\
7 \text { models }\end{array}$ & $\begin{array}{l}\text { GARCH } \\
0 \text { model }\end{array}$ & $\begin{array}{l}\text { OLS-HAC } \\
6 \text { models }\end{array}$ & $\begin{array}{l}\text { GARCH } \\
1 \text { model }\end{array}$ \\
\hline \multicolumn{7}{|c|}{ Concurrent $\beta_{i, 0}$} \\
\hline++ & 0 & - & 1 & - & 1 & 0 \\
\hline+ & 4 & - & 5 & - & 0 & 1 \\
\hline-- & 1 & - & 0 & - & 0 & 0 \\
\hline- & 2 & - & 1 & - & 5 & 0 \\
\hline \multicolumn{7}{|c|}{$\operatorname{Lag} \beta_{i,-1}$} \\
\hline++ & 0 & - & 0 & - & 0 & 0 \\
\hline+ & 3 & - & 5 & - & 4 & 1 \\
\hline-- & 2 & - & 1 & - & 0 & 0 \\
\hline- & 2 & - & 1 & - & 2 & 0 \\
\hline \multicolumn{7}{|c|}{ Lead $\beta_{i,+1}$} \\
\hline++ & 0 & - & 0 & - & 0 & 0 \\
\hline+ & 2 & - & 2 & - & 2 & 0 \\
\hline-- & 1 & - & 2 & - & 1 & 0 \\
\hline- & 4 & - & 3 & - & 3 & 1 \\
\hline
\end{tabular}

Notes: The table is based on the whole sample period from January 2, 2012, to December 30, 2016.

++ positive significant coefficient

+ positive insignificant coefficient

- - negative significant coefficient

- negative insignificant coefficient

Source: author's own calculations with the use of STATA 14. 
The summarized cross-sectional results reported in Table 3 require comments. The regressions provide no pronounced evidence of commonality in liquidity on the CEE markets because positive and statistically significant coefficients are scarce, especially in the case of the $M A m i h_{t}$ and $S_{t}$ proxies. For example, the positive and statistically significant concurrent coefficients constitute $2 / 10$ (1/10), 0/18 (2/18), 0/3 (0/3), 0/15 $(0 / 15), 0 / 12(0 / 12)$, and 0/7 (1/7) of all concurrent coefficients for the PSE, BSE, BSSE, NASDAQ Vilnius, NASDAQ Tallinn, and NASDAQ Riga models, and the $\operatorname{MAmih}_{t}\left(S_{t}\right)$ proxies, respectively. The evidence concerning the lag and lead coefficients is very similar. Moreover, for both the $M A m i h_{t}$ and $S_{t}$ measures, the numbers of negative and statistically significant coefficients are even greater for some investigated markets, which informs about liquidity co-movements in the opposite direction. This phenomenon observed for these two estimates could be explained by their relatively high sensitivity to non-trading effects (Corwin, Schultz 2012; Olbryś 2019a). The empirical results for the $\% R S_{t}$ proxy are slightly different. We observe more positive coefficients, but many of them are insignificant. For example, the positive and statistically significant (insignificant) concurrent coefficients constitute 6/10 (4/10), 9/18 (6/18), 0/3 (3/3), 6/15 $(8 / 15), 5 / 12(3 / 12)$, and $1 / 7$ (5/7) of all concurrent coefficients for the PSE, BSE, BSSE, NASDAQ Vilnius, NASDAQ Tallinn, and NASDAQ Riga models, respectively. The findings concerning the lag and lead coefficients are similar.

\section{Robustness tests}

The related literature indicates that commonality in liquidity varies over time (e.g., Kamara et al. 2008; Karolyi et al. 2012). Therefore, to check the robustness of the empirical results, the time rolling-window approach is employed. The whole sample period covers five years; therefore, robustness tests based on the 2-year rolling-window are provided. Three 2-year time windows are utilized:

- Window 1 (January 2012 - December 2014),

- Window 2 (January 2013 - December 2015),

- Window 3 (January 2014 - December 2016).

The parameters of model (1) are estimated for each stock that is contained in the database, within each time window, and for each of three liquidity proxies. In total, 585 models are investigated, comprising 90 models for the PSE, 162 models for the BSE, 27 models for the BSSE, 135 models for the NASDAQ Vilnius, 108 models for the NASDAQ Tallinn, and 63 models for the NASDAQ Riga.

The results of the rolling-window tests are presented in Tables 4-6. These results reveal that in the case of the MAmih ${ }_{t}$ and $S_{t}$ proxies (Tables 4 and 6), the numbers of positive and statistically significant coefficients are predominately equal to zero for each window, and for all stock exchanges. Moreover, the proportions of negative and statistically significant coefficients are even greater, which informs about liquidity movements in the opposite direction. In the case of the $\% R S_{t}$ proxy, the empirical findings 
No Commonality in Liquidity on Small Emerging Markets...

are slightly better, especially for the Prague, Budapest, Vilnius, and Tallinn stock exchanges (Table 5). However, one can observe that robustness tests based on the 2-year rolling-window approach indicate no reason to reject the research hypothesis that there is no commonality in liquidity on the six stock markets considered separately.

Table 4. The rolling-window findings of testing for stock exchange-level commonality in liquidity on six small CEE stock markets (the MAmih proxy)

\begin{tabular}{|c|c|c|c|}
\hline \multirow[t]{2}{*}{ Coefficient } & \multicolumn{3}{|c|}{$\begin{array}{l}\text { The proportion of positive/negative and statistically significant } \\
\text { slope coefficients }\end{array}$} \\
\hline & Window 1 & Window 2 & Window 3 \\
\hline \multicolumn{4}{|c|}{ Prague (10 models) } \\
\hline Concurrent $\beta_{i, 0}$ & $1 / 2$ & $1 / 2$ & $3 / 2$ \\
\hline $\operatorname{Lag} \beta_{i,-1}$ & $0 / 0$ & $0 / 1$ & $0 / 1$ \\
\hline Lead $\beta_{i, 1}$ & $0 / 3$ & $1 / 3$ & $0 / 1$ \\
\hline \multicolumn{4}{|c|}{ Budapest (18 models) } \\
\hline Concurrent $\beta_{\mathrm{i}, 0}$ & $0 / 6$ & $0 / 8$ & $0 / 8$ \\
\hline $\operatorname{Lag} \beta_{i,-1}$ & $0 / 6$ & $1 / 7$ & $0 / 9$ \\
\hline Lead $\beta_{i, 1}$ & $0 / 5$ & $1 / 5$ & $0 / 4$ \\
\hline \multicolumn{4}{|c|}{ Bratislava (3 models) } \\
\hline Concurrent $\beta_{\mathrm{i}, 0}$ & $0 / 1$ & $0 / 1$ & $0 / 1$ \\
\hline $\operatorname{Lag} \beta_{i,-1}$ & $0 / 1$ & $0 / 0$ & $0 / 2$ \\
\hline Lead $\beta_{i,+1}$ & $0 / 1$ & $0 / 3$ & $0 / 3$ \\
\hline \multicolumn{4}{|c|}{ Vilnius (15 models) } \\
\hline Concurrent $\beta_{\mathrm{i}, 0}$ & $1 / 1$ & $0 / 3$ & $0 / 8$ \\
\hline $\operatorname{Lag} \beta_{i,-1}$ & $0 / 5$ & $0 / 4$ & $0 / 5$ \\
\hline Lead $\beta_{i, 1}$ & $0 / 2$ & $0 / 2$ & $0 / 3$ \\
\hline \multicolumn{4}{|c|}{ Tallinn (12 models) } \\
\hline Concurrent $\beta_{i, 0}$ & $0 / 2$ & $1 / 3$ & $0 / 4$ \\
\hline Lag $\beta_{i,-1}$ & $0 / 4$ & $0 / 3$ & $0 / 3$ \\
\hline Lead $\beta_{i, 1}$ & $0 / 4$ & $0 / 2$ & $0 / 2$ \\
\hline \multicolumn{4}{|c|}{ Riga (7 models) } \\
\hline Concurrent $\beta_{\mathrm{i}, 0}$ & $0 / 0$ & $0 / 2$ & $0 / 2$ \\
\hline $\operatorname{Lag} \beta_{i,-1}$ & $0 / 1$ & $0 / 2$ & $0 / 1$ \\
\hline Lead $\beta_{\mathrm{i},+1}$ & $0 / 4$ & $0 / 1$ & $0 / 1$ \\
\hline
\end{tabular}

Notation as in Table 3. The significance level is equal to $10 \%$.

Window 1: January 2012 - December 2014; Window 2: January 2013 - December 2015; Window 3: January 2014 - December 2016.

Source: author's own calculations with the use of STATA 14. 
Joanna Olbryś

Table 5. The rolling-window findings of testing for stock exchange-level commonality in liquidity on six small CEE stock markets (the \%RS proxy)

\begin{tabular}{|l|c|c|c|}
\hline \multicolumn{1}{|c|}{ Coefficient } & \multicolumn{1}{c|}{ The proportion of positive/negative and statistically significant } \\
slope coefficients
\end{tabular}

Notation as in Table 4.

Source: author's own calculations with the use of STATA 14. 
No Commonality in Liquidity on Small Emerging Markets...

Table 6. The rolling-window findings of testing for stock exchange-level commonality in liquidity on six small CEE stock markets (the $S_{t}$ proxy)

\begin{tabular}{|c|c|c|c|}
\hline \multirow[t]{2}{*}{ Coefficient } & \multicolumn{3}{|c|}{$\begin{array}{c}\text { The proportion of positive/negative and statistically significant } \\
\text { slope coefficients }\end{array}$} \\
\hline & Window 1 & Window 2 & Window 3 \\
\hline \multicolumn{4}{|c|}{ Prague (10 models) } \\
\hline Concurrent $\beta_{i, 0}$ & $2 / 2$ & $1 / 0$ & $0 / 0$ \\
\hline $\operatorname{Lag} \beta_{\mathrm{i},-1}$ & $1 / 0$ & $1 / 0$ & $0 / 0$ \\
\hline Lead $\beta_{i,+1}$ & $0 / 0$ & $0 / 0$ & $1 / 2$ \\
\hline \multicolumn{4}{|c|}{ Budapest (18 models) } \\
\hline Concurrent $\beta_{\mathrm{i}, 0}$ & $3 / 2$ & $3 / 2$ & $1 / 1$ \\
\hline Lag $\beta_{i,-1}$ & $1 / 2$ & $1 / 1$ & $1 / 0$ \\
\hline Lead $\beta_{\mathrm{i},+1}$ & $0 / 1$ & $0 / 2$ & $0 / 2$ \\
\hline \multicolumn{4}{|c|}{ Bratislava (3 models) } \\
\hline Concurrent $\beta_{\mathrm{i}, 0}$ & $0 / 0$ & $0 / 0$ & $0 / 2$ \\
\hline $\operatorname{Lag} \beta_{\mathrm{i},-1}$ & $1 / 0$ & $0 / 0$ & $0 / 0$ \\
\hline Lead $\beta_{i,+1}$ & $1 / 0$ & $2 / 0$ & $0 / 1$ \\
\hline \multicolumn{4}{|c|}{ Vilnius (15 models) } \\
\hline Concurrent $\beta_{i, 0}$ & $0 / 0$ & $0 / 0$ & $0 / 1$ \\
\hline $\operatorname{Lag} \beta_{\mathrm{i},-1}$ & $3 / 0$ & $4 / 1$ & $3 / 0$ \\
\hline Lead $\beta_{i,+1}$ & $0 / 0$ & $2 / 0$ & $3 / 0$ \\
\hline \multicolumn{4}{|c|}{ Tallinn (12 models) } \\
\hline Concurrent $\beta_{i, 0}$ & $0 / 0$ & $0 / 1$ & $0 / 1$ \\
\hline Lag $\beta_{\mathrm{i},-1}$ & $0 / 1$ & $0 / 0$ & $0 / 0$ \\
\hline Lead $\beta_{i,+1}$ & $1 / 0$ & $2 / 0$ & $1 / 0$ \\
\hline \multicolumn{4}{|c|}{ Riga (7 models) } \\
\hline Concurrent $\beta_{i, 0}$ & $1 / 0$ & $1 / 0$ & $1 / 0$ \\
\hline $\operatorname{Lag} \beta_{i,-1}$ & $0 / 0$ & $0 / 0$ & $2 / 0$ \\
\hline Lead $\beta_{\mathrm{i},+1}$ & $0 / 1$ & $0 / 1$ & $0 / 0$ \\
\hline
\end{tabular}

Notation as in Table 4.

Source: author's own calculations with the use of STATA 14.

\section{Discussion and conclusions}

The purpose of this comparative study was to assess market-wide commonality in liquidity on six emerging Central and Eastern European stock exchanges, in the Czech Republic, Hungary, Slovakia, Lithuania, Estonia, and Latvia. The modified version of the Amihud proxy, the percentage relative spread bid/ask, and the Corwin-Schultz 
high-low two-day spread estimator were utilized as daily liquidity/illiquidity measures for stocks. The OLS regression with the HAC covariance matrix estimation and the GARCH-type models were employed to infer the patterns of intra-market commonality in liquidity on the investigated exchanges. According to the literature, positive and statistically significant slope coefficients in the estimated models are especially desired, as they indicate co-movements in liquidity in the same direction, and therefore confirm commonality in liquidity.

In general, the estimation results provide no evidence of co-movements in liquidity on the CEE stock exchanges because positive and statistically significant coefficients rarely appear, regardless of the choice of the liquidity estimate. The empirical findings are somewhat homogeneous for all investigated markets. Therefore, no reason has been found to reject the research hypothesis that there is no commonality in liquidity on the CEE stock markets, taken separately. This is perhaps the most significant finding of our research. The results are novel and generally consistent with the literature concerning other emerging markets in the world but are in contrast to previous studies of developed markets. The findings fill the gap in the literature of commonality in liquidity on emerging and frontier markets, and therefore, our study contributes to the body of knowledge in that respect. Moreover, this paper proposes attributing the absence of commonality in liquidity on the small CEE stock exchanges mainly to the non-trading problem. It is worth noting that commonality in liquidity may depend on the structure of the stock market, and it is less pronounced in order-driven markets than for dealer or hybrid markets because quote-driven or hybrid systems offer a form of liquidity supplier.

The results of this research have important practical implications and may be useful in decision-making processes. From a practical point of view, the problem is crucial because the absence of commonality in liquidity influences investment strategies, portfolio management and risk diversification, domestic and international asset pricing, etc. Moreover, empirical findings concerning liquidity co-movements would help regulators and policymakers in improving stock market design. Undoubtedly, a low level of commonality in liquidity has some advantages because it reduces the susceptibility of a country's financial system to the drying up of liquidity across many securities during periods of market stress and crisis (Karolyi et al. 2012).

The empirical results presented in this study certainly cannot provide definitive conclusions as to commonality in liquidity on the investigated markets. Selected liquidity proxies based on daily data are utilized. According to the literature, there are several existing liquidity measures, and different frequencies of data are used. Various proxies derived from intraday data are particularly useful and frequently employed in assessing commonality in liquidity (e.g., Pukthuanthong-Le, Visaltanachoti 2009; Narayan et al. 2015; Olbryś 2019a). However, high-frequency data are not freely available for the analyzed CEE stock exchanges, and this is the main limitation of the study. 
A possible direction for further investigation could be to identify components of liquidity on the CEE stock markets taken separately, applying methods based on principal component analysis. To the best of the author's knowledge, no such research has been undertaken thus far. Another important direction for further research could be a comparative investigation of commonality in liquidity on the same six small CEE stock exchanges before and after the COVID-19 pandemic. In all likelihood, the less liquid emerging stock markets will be among the most affected by the worldwide recession. Many firms will have serious problems surviving the COVID-19 pandemic period, and it is possible that the number of companies listed on small stock exchanges will substantially change. However, the non-trading problem will increase.

\section{References}

Amihud, Y. (2002), Illiquidity and Stock Returns: Cross-Section and Time-Series Effects, "Journal of Financial Markets", 5 (1), https://doi.org/10.1016/S1386-4181 (01)00024-6 Bai, M., Qin, Y. (2015), Commonality in Liquidity in Emerging Markets: Another Supply-Side Explanation, "International Review of Economics \& Finance", 39, https:// doi.org/10.1016/j.iref.2015.06.005

Bekaert, G., Harvey, C.R., Lundblad, C. (2007), Liquidity and Expected Returns: Lessons from Emerging Markets, "Review of Financial Studies", 20 (6), https://doi.org /10.1093/rfs/hhm030

Będowska-Sójka, B. (2019), Commonality in Liquidity Measures. The Evidence from the Polish Stock Market, "Hradec Economic Days", 9 (1).

Brockman, P., Chung, D.Y., Perignon, C. (2009), Commonality in Liquidity: A Global Perspective, "Journal of Financial and Quantitative Analysis", 44 (4), https://doi.org /10.1017/S0022109009990123

Chordia, T., Roll, R., Subrahmanyam, A. (2000), Commonality in Liquidity, "Journal of Financial Economics”, 56 (1), https://doi.org/10.1016/S0304-405X(99)00057-4

Corwin, S.A., Schultz, P. (2012), A Simply Way to Estimate Bid-Ask Spreads from Daily High and Low Prices, "Journal of Finance", 67 (2), https://doi.org/10.1111/j.1540 -6261.2012.01729.x

Dickey, D.A., Fuller, W.A. (1981), Likelihood Ratio Statistics for Autoregressive Time Series with a Unit Root, "Econometrica", 49 (4), https://doi.org/10.2307/1912517

Dimson, E. (1979), Risk Measurement when Shares are Subject to Infrequent Trading, "Journal of Financial Economics", 7, https://doi.org/10.1016/0304-405X(79)90013-8

Elliott, G., Rothenberg, T.J., Stock, J.H. (1996), Efficient Tests for an Autoregressive Unit Root, "Econometrica", 64 (4), https://doi.org/10.2307/2171846

Engle, R.F. (1982), Autoregressive Conditional Heteroscedasticity with Estimates of the Variance of United Kingdom Inflations, "Econometrica", 50, https://doi.org/10.23 07/1912773

Fong, K.Y.L., Holden, C.W., Trzcinka, C. (2017), What are the Best Liquidity Proxies for Global Research?, "Review of Finance”, 21, https://doi.org/10.1093/rof/rfx003 
Kamara, A., Lou, X., Sadka, R. (2008), The Divergence of Liquidity Commonality in the Cross-Section of Stocks, "Journal of Financial Economics”, 89 (3), https://doi.org/10 .1016/j.jineco.2007.10.004

Kang, W., Zhang, H. (2013), Limit Order Book and Commonality in Liquidity, "Financial Review", 48 (1), https://doi.org/10.1111/j.1540-6288.2012.00348.x

Karolyi, G.A., Lee, K.-H., van Dijk, M.A. (2012), Understanding Commonality in Liquidity Around the World, "Journal of Financial Economics", 105 (1), https://doi.org /10.1016/j.jfineco.2011.12.008

Kearney, C. (2012), Emerging Markets Research: Trends, Issues, and Future Directions, "Emerging Markets Review", 13 (2), https://doi.org/10.1016/j.ememar.2012.01.003

Kiviaho, J., Nikkinen, J., Piljak, V., Rothovius, T. (2014), The Comovement Dynamics of European Frontier Stock Markets, "European Financial Management”, 20 (3), https://doi.org/10.1111/j.1468-036X.2012.00646.x

Korajczyk, R., Sadka, R. (2008), Pricing the Commonality Across Alternative Measures of Liquidity, "Journal of Financial Economics", 87 (1), https://doi.org/10.1016/j.jfine co.2006.12.003

Narayan, P.K., Zhang, Z., Zheng, X. (2015), Some Hypotheses on Commonality in Liquidity: New Evidence from the Chinese Stock Market, "Emerging Markets Finance \& Trade”, 51, https://doi.org/10.1080/1540496X.2015.1061799

Newey, W.K., West, K.D. (1987), A Simple, Positive Semi-Define, Heteroskesticity and Autocorrelation Consistent Covariance Matrix, "Econometrica”, 55 (3), https://doi .org/10.2307/1913610

Olbryś, J. (2014), Is Illiquidity Risk Priced? The Case of the Polish Medium-Size Emerging Stock Market, "Bank i Kredyt", 45 (6).

Olbryś, J. (2018), The Non-Trading Problem in Assessing Commonality in Liquidity on Emerging Stock Markets, "Dynamic Econometric Models", 18, https://doi.org /10.12775/DEM.2018.004

Olbryś, J. (2019a), Intra-Market Commonality in Liquidity. New Evidence from the Polish Stock Exchange, "Equilibrium. Quarterly Journal of Economics and Economic Policy”, 14 (2), https://doi.org/10.24136/eq.2019.012

Olbryś, J. (2019b), Market-Wide Commonality in Liquidity on the CEE-3 Emerging Stock Markets, [in:] K. Jajuga, H. Locarek-Junge, L.T. Orlowski, K. Staehr (eds), Contemporary Trends and Challenges in Finance, Springer Nature Switzerland AG, https:// doi.org/10.1007/978-3-030-15581-0_13

Olbryś, J. (2020), Market Tightness on the CEE Emerging Stock Exchanges in the Context of the Non-Trading Problem, [in:] N. Tsounis, A. Vlachvei (eds), Advances in Cross-Section Data Methods in Applied Economic Research. Springer Nature Switzerland AG, https://doi.org/10.1007/978-3-030-38253-7_36

Olbryś, J., Mursztyn, M. (2018), On Some Characteristics of Liquidity Proxy Time Series. Evidence from the Polish Stock Market, [in:] N. Tsounis, A. Vlachvei (eds), Advances in Time Series Data Methods in Applied Economic Research, Springer Nature Switzerland AG, https://doi.org/10.1007/978-3-030-02194-8_13

Pukthuanthong-Le, K., Visaltanachoti, N. (2009), Commonality in Liquidity: Evidence from the Stock Exchange of Thailand, "Pacific-Basin Finance Journal", 17 (1), https:// doi.org/10.1016/j.pacfin.2007.12.004 
Sensoy, A. (2016), Commonality in Liquidity: Effects of Monetary Policy and Macroeconomic Announcements, "Finance Research Letters", 16, https://doi.org/10.1016 /j.frl.2015.10.021

Syamala, R., Wadhwa, K., Goyal, A. (2017), Determinants of Commonality in Liquidity: Evidence from an Order-Driven Emerging Market, "North American Journal of Economics and Finance", 42, https://doi.org/10.1016/j.najef.2017.07.003

Wang, J. (2013), Liquidity Commonality Among Asian Equity Markets, "Pacific-Basin Finance Journal”, 21 (1), https://doi.org/10.1016/j.pacfin.2012.05.001

\section{Streszczenie}

\section{Brak wspólności w płynności na małych rozwijających się rynkach giełdowych? Wyniki dla giełd Europy Środkowo-Wschodniej}

Celem pracy było badanie komparatywne tzw. wspólności w płynności (commonality in liquidity) na sześciu małych giełdach Europy Środkowo-Wschodniej. Analizowane rynki to: Czechy, Węgry, Słowacja, Litwa, Estonia i Łotwa. Wykorzystano trzy miary płynności/niepłynności aktywów kapitałowych, aproksymowane na podstawie danych dziennych. Próba objęła okres 5 lat, od stycznia 2012 do grudnia 2016. Do oszacowania modeli płynności zastosowano metodę estymatorów odpornych HAC oraz modele typu GARCH (w przypadku wystąpienia efektu ARCH w procesach resztowych). Dodatkowo przeprowadzono analizę stabilności wyników w czasie za pomocą procedury ruchomego okna. Wyniki empiryczne nie ujawniły wyraźnych wzorców w płynności na badanych rynkach oraz okazały się bardzo zbliżone na wszystkich giełdach, analizowanych oddzielnie. Na tej podstawie stwierdzono brak podstaw do odrzucenia hipotezy badawczej o braku wspólności w płynności na każdym z rynków. Badanie wypełnia lukę literaturową dotyczącą płynności na małych giełdach Europy Środkowo-Wschodniej, ponieważ żadne z wcześniejszych opracowań nie analizowało w sposób kompleksowy całej grupy wymienionych rynków.

Słowa kluczowe: Europa Środkowo-Wschodnia, wspólność w płynności, GARCH, HAC, ruchome okno czasowe, dane dzienne 